\title{
Campylobacter pylori in the upper gastrointestinal tract of patients with HIV-1 infection
}

\author{
N D Francis, R P H Logan, M M Walker, R J Polson, A W Boylston, A J Pinching, \\ J R W Harris, J H Baron
}

\begin{abstract}
Fifty one patients with human immunodeficiency virus (HIV-1) infection who had been consecutively endoscoped for upper gastrointestinal symptoms were biopsied (stomach or duodenum, or both) and compared with 59 age and sex matched controls for the presence of Campylobacter pylori. In $28(47 \%)$ of the control group but in only seven (14\%) of the HIV seropositive patients were $C$ pylori seen on histological examination $(p<0.001$, odds ratio $5.6,95 \%$ confidence interval 2-2-14.5). Sixteen patients who were HIV antibody positive had other index diseases for the diagnosis of AIDS in the biopsy material and, when these were excluded, comparison with the control group still showed a significant difference; $p<0 \cdot 01$, odds ratio $3 \cdot 6,95 \%$, confidence interval 1.4-9.6. In this series, therefore, $C$ pylori were far less common in HIV antibody positive patients than in controls. Among the HIV positive patients, a higher proportion of $C$ pylori negative cases had AIDS but this trend was not significant.

The findings of this study indicate that whatever abnormalities of cell mediated mucosal immunoregulation are caused by HIV infection, they do not seem to be important in the response to infection by C pylori.
\end{abstract}

Considerable evidence now links the presence of Campylobacter pylori with chronic type B (non-autoimmune) gastritis and duodenal ulceration ${ }^{1-3}$; when it is present almost invariably there is histological evidence of gastritis. ${ }^{45}$ $C$ pylori is found in the gastric mucosa of up to $90 \%$ of patients with a duodenal ulcer, in $70 \%$ with gastric ulcer, and in $60 \%$ of patients with non-ulcer dyspepsia. ${ }^{6}$ There is also serological evidence of $C$ pylori infection in up to $20 \%$ of the adult population even when asymptomatic, a similar prevalence histologically in normal volunteers, ${ }^{7}$ and a $40-65 \%$ prevalence in unselected patients undergoing upper gastrointestinal endoscopy. ${ }^{8}$ Patients infected with human immunodeficiency virus (HIV-1), with or without AIDS, have a high incidence (50$90 \%$ ) of gastrointestinal symptoms.

This study was undertaken to assess the incidence of $C$ pylori in histological specimens from HIV antibody positive patients and to estalish what histological abnormalities were associated with the presence of these organ- isms. Comparison was made with an age and sex matched control group. We set out to answer the following questions: Does the incidence of $C$ pylori differ from the normal population or from HIV antibody negative patients with upper gastrointestinal symptoms? Does HIV infection, therefore, increase susceptibility to infection by $C$ pylori? Is there more or less tissue damage in HIV antibody positive, than in HIV antibody negative, patients with $C$ pylori?

\section{Methods}

Fifty one HIV antibody positive patients consecutively examined by upper gastrointestinal endoscopy were studied. All had three or four gastric biopsy specimens taken from the body and antrum, and most underwent duodenal biopsy. Fifty nine age and sex matched HIV antibody negative controls were compared with the study group. The case controls were recruited from a group of 200 patients already being endoscoped for upper gastrointestinal symptoms and studied for $C$ pylori. All of the control group also had body, antral, or duodenal biopsy specimens taken. Criteria for endoscopy were presentation with any upper gastrointestinal symptoms and were similar in study and control groups.

Biopsy specimens were examined at multiple levels by light microscopy, having been stained with haematoxylin and eosin and the Giminez technique to facilitate identification of $C$ pylori. The degree of inflammation and type of gastritis were assessed-normal, chronic gastritis, active chronic gastritis, active atrophic gastritis, acute gastritis-using the Whitehead classification, where the term active indicates the presence of polymorphs. Duodenitis was also assessed and the presence of gastric metaplasia noted.

Results were analysed for confidence interval for an unmatched case control study and differences in proportions of $C$ pylori negative cases with or without AIDS were analysed by the $\chi^{2}$ test.

\section{Results}

Twenty eight $(47 \%)$ of the control group but only seven $(14 \%)$ of the HIV patients were positive for $C$ pylori on histological examination ( $p<0.001$, odds ratio $5.6,95 \%$ confidence interval 2.2-14.5). Sixteen patients in the HIV group had an AIDS index disease diagnosed on the biopsy material received, but no $C$ pylori. These were cytomegalovirus, Kaposi's sar-
N D Francis, Department of Histopathology, Westminste 2AR.

Accepted for publication 10 August 1989 
Table $1 C$ pylori positivity in cases and controls

\begin{tabular}{llll}
\hline & $\begin{array}{l}\text { HIV positive } \\
\text { (other gastro- } \\
\text { intestinal } \\
\text { disease } \\
\text { excluded) }\end{array}$ & HIV positive & $\begin{array}{l}\text { HIV negative } \\
\text { controls }\end{array}$ \\
\hline Total with & & 7 & 28 \\
$\begin{array}{c}\text { C pylori } \\
\text { Total number }\end{array}$ & 75 & 51 & 59 \\
\hline
\end{tabular}

coma, lymphoma and cryptosporidia. Two cases of giardiasis were also seen. These 16 were excluded from further study or comparison. When the remainder were compared with the controls there was still a significant difference $\mathrm{p}<0.01$, odds ratio $3.6,95 \%$ confidence, interval 1.4-9.6 (table 1).

Details of the HIV positive $C$ pylori positive cases are shown in table 2. Two of these cases had coexistent cryptosporidia, one seen in the duodenal biopsy specimen and one in a stool sample.

Most of the patients had not received any treatment in the four weeks before investigation and none had received bismuth compounds or amoxycillin; nor had they received other drugs in doses or combinations recognised to be effective against $C$ pylori (table 3 ).

In the HIV antibody positive $C$ pylori negative patients the proportion of AIDS to non-AIDS cases was 10:18. This was not significantly different from the 1:6 ratio in the HIV antibody positive $C$ pylori positive cases $(p>0.5)$. Although there was a trend, there was no definite correlation with the stage of disease in HIV infection.

The histological features associated with $C$ pylori infection in the HIV antibody positive patients were not different from those seen in either the HIV antibody negative cases or from previous reports. There was inflammation in the lamina propria in all except case 4 in whom $C$ pylori were found in the duodenum (with inflammation) but not in the normal gastric biopsy specimens. Five of the remaining cases had active gastritis and one had chronic inflammation without polymorphs. This was similar to the findings in the control group where the presence of $C$ pylori was associated with active inflammation in 17 and chronic inflammation in 11. None of the control group had normal gastric biopsy histology in association with $C$ pylori.

Analysis of intraepithelial lymphocyte numbers was not carried out as this is the subject of a separate study. We did not observe any subjective differences, however, between the
Table 3 Treatment received by HIV positive patients during four weeks before biopsy

\begin{tabular}{|c|c|}
\hline No of cases & Treatment \\
\hline \multicolumn{2}{|l|}{$C$ pylori positive: } \\
\hline $\begin{array}{l}4 \\
1\end{array}$ & $\begin{array}{l}\text { Nil } \\
\text { Ganciclovir }\end{array}$ \\
\hline 1 & zidovudine, ketoconazole \\
\hline 1 & $\begin{array}{l}\text { Ampicillin and flucloxacillin } \\
(1 / 52 \text { PRIOR) fluconazole }\end{array}$ \\
\hline \multicolumn{2}{|l|}{$C$ pylori negative: } \\
\hline 16 & Nil \\
\hline 3 & Ketoconazole \\
\hline 3 & Rifampicin, ethambutol, pyrizinamide \\
\hline 2 & Ganciclovir \\
\hline 1 & Ganciclovir, ketoconazole \\
\hline 1 & Ganciclovir, fluconazole \\
\hline 1 & $\begin{array}{l}\text { Erythromycin, sulphasalazine } \\
\text { (1/52 PRIOR) ketoconazole, acyclovir }\end{array}$ \\
\hline 1 & $\begin{array}{l}\text { Cyclophosphamide, adriamicin, } \\
\text { vincristine, prednisone, for } \\
\text { non-Hodgkin's lymphoma }\end{array}$ \\
\hline Total 35 & \\
\hline
\end{tabular}

controls and the groups with HIV with $C$ pylori in this respect.

\section{Discussion}

This is the first case control study of $C$ pylori in HIV infection as far as we know and our results show that the incidence is significantly lower than in endoscopically negative patients with upper gastrointestinal symptoms and similar to that found in normal volunteers. Campylobacter jejuni and other Campylobacter-like organisms have been found in homosexual men with enterocolitis or bacteraemia ${ }^{10}$ but there has only been one case report of $C$ pylori in a patient with AIDS. ${ }^{11}$ A study of $C$ pylori antibody titres in homosexual men suggested that the prevalence of the organism was higher than in normal controls. ${ }^{12}$ It might therefore be expected that this infection would also be commoner in patients infected with HIV, but this is not borne out by our study.

Meiselman's case was reported as having an unusually aggressive course with histological invasion of Campylobacter into the mucosal lamina propria. ${ }^{11}$ There was evidence of mucosal erosion, however, and the invasion may therefore have been a secondary event. It was also implied that reduced mucosal immunity might explain the clinical course and florid histology and that this suggested immunological events in the control of $C$ pylori infection.

In our positive cases neither the clinical nor histological features were unusually severe or aggressive and they were similar to those described and seen in HIV antibody negative patients infected with $C$ pylori. This suggests

Table 2 HIV positive patients with C pylori identified on biopsy

\begin{tabular}{|c|c|c|c|c|c|}
\hline $\begin{array}{l}\text { Case No with } \\
\text { HIV|AIDS }\end{array}$ & Gastric histology & $C P$ & Duodenal histology & $C P$ & Clinical details \\
\hline $1 \mathrm{HIV}+$ & Active atrophic gastritis & + & Normal & - & $\begin{array}{l}\text { Diarrhoea, cryptosporidia } \\
\text { (stool) }\end{array}$ \\
\hline 2 AIDS & Chronic gastritis & + & Normal & - & Dyspepsia \\
\hline $3 \mathrm{HIV}+$ & Active atrophic gastritis & + & $\begin{array}{l}\text { Mild chronic duodenitis, } \\
\text { cryptosporidia }\end{array}$ & - & $\begin{array}{l}\text { Recurrent vomiting, mild } \\
\text { gastritis }\end{array}$ \\
\hline $4 \mathrm{HIV}+$ & Normal & - & $\begin{array}{l}\text { Chronic duodenitis (gastric } \\
\text { metaplasia) }\end{array}$ & + & Painful dysphagia \\
\hline $5 \mathrm{HIV}+$ & Active chronic gastritis & + & Chronic duodenitis & - & $\begin{array}{l}\text { Abdominal pain, atypical } \\
\text { gastritis }\end{array}$ \\
\hline $\begin{array}{l}6 \text { HIV + } \\
7 \text { HIV + }\end{array}$ & $\begin{array}{l}\text { Acute gastritis, ulcer } \\
\text { Acute gastritis }\end{array}$ & $\begin{array}{l}+ \\
+\end{array}$ & $\begin{array}{l}\text { No biopsy } \\
\text { No biopsy }\end{array}$ & & $\begin{array}{l}\text { Haematemesis, small erosion } \\
\text { Dyspepsia }\end{array}$ \\
\hline
\end{tabular}


that the immune response and tissue damage normally elicited by $C$ pylori infection is not noticeably affected by HIV infection.

The role of $C$ pylori infection in causing symptoms is unknown at present. Although this was not a question we could specifically answer from this retrospective study, we conclude that in the small number of $C$ pylori positive patients infection with this organism was likely to be responsible for their symptoms and histological evidence of inflammation. While this represents a relatively small percentage of gastrointestinal disease in the HIV population, a high proportion of patients with HIV have gastrointestinal symptoms; a diagnosis of $C$ pylori infection may therefore be important in clinical management.

Intestinal mucosal immunity in HIV infection has not been studied directly, but analysis of mucosal lymphocyte populations has shown decreased T11 positive cells with decreased $\mathrm{T} 4$, increased $\mathrm{T} 8$ numbers, and a reversal of the T4:T8 ratio. ${ }^{13}$ These findings suggest that there is impaired local cell mediated immunity permitting infection by opportunistic and other organisms as well as persistence of HIV. The low incidence of $C$ pylori in our study group does not support the view that HIV infection or AIDS predisposes to this infection; indeed, it suggests the opposite.

If reduced mucosal $T$ cell dependent immunity were a main predisposing factor in colonisation by $C$ pylori then we would expect to find an increased incidence of HIV antibody positive patients and, by extension, significantly fewer cases of AIDS in the $C$ pylori negative group. Although there was a trend towards the latter, our results showed no significant difference in $C$ pylori negativity between HIV antibody positive patients with or without AIDS.

Our observations and those of others show that a large proportion of HIV antibody positive patients have no potential secondary pathogen or process to explain the gastrointestinal symptoms after biopsy, bacteriological, and virological investigations. This has led to the suggestion that HIV has enteropathogenic effects of its own..$^{1415}$

The explanation for the low prevalence of $C$ pylori in this study, compared with other patients with upper gastrointestinal symptoms, is not fully explained by the presence of HIV associated diseases. An interaction with other organisms such as cryptosporidia (as in two of our cases) could have had an effect on $C$ pylori colonisation. Another possibility is that antibodies to $C$ pylori are non-specifically raised due to the early HIV associated polyclonal rise in gammaglobulins and that the bacteria are partially or completely eradicated, or infection prevented. It is also possible that infection of gut epithelial cells and lamina propria monocytes and macrophages by HIV changes the local environment and mucus, therefore inhibiting colonisation and survival.

Some of our patients were receiving or had recently completed treatment for other complications of HIV infection. None had received bismuth compounds, amoxycillin, or other drug combinations recongnised to be effective against $C$ pylori in the four weeks before investigation. We cannot be certain, however, that other therapeutic or prophylactic agents received by some of the patients did not have some activity against $C$ pylori, either directly or indirectly. We are now conducting a prospective study of $C$ pylori infection in HIV positive patients.

As the prevalence of $C$ pylori infection in our study is comparable with that of normal controls, HIV infection does not seem to increase susceptibility to these organisms. The corollary of this is that cell mediated immunity is not involved in the control of $C$ pylori infection.

1 Warren JR, Marshall BJ. Unidentified curved bacilli on gastric mucosa in active chronic gastritis. Lancet 1983 gastric mucc

2 Marshall BJ, Goodwin CS, Warren JR, et al. Prospective double-blind trial of duodenal ulcer relapse after eradication of Campylobacter pylori. Lancet 1988;ii:1437-41.

3 Goodwin CS. Duodenal ulcer, Campylobacter pylori and the "leaking roof" concept. Lancet 1988;ii:1467-9.

4 Rathbone BJ, Wyatt JI, Worsley BW, Trejdosiewicz LK, Heatley RV, Losowsky MS. Immune response to Campylobacter pyloridis. Lancet $1985 ; \mathrm{i}: 1217$.

5 Rathbone BJ, Wyatt JI, Worsley BW, et al. Sytemic and local antibody responses to Campylobacter pyloridis in local antibody responses to Campylobact

6 Marshall BJ, McGechie DB, Rogers PA, Glancy RJ. Pyloric Campylobacter infection and gastroduodenal disease. Med J Aust 1985;142:439-44.

7 Graham DY, Klein PD, Evans DJ, et al. Campylobacter pylori detected noninvasively by the ${ }^{13} \mathrm{C}$-urea breath test. Lancet 1987;ii:1174-7.

8 Taylor DE, Hargreaves JA, Ng LK, Sherbaniuk RW, Jewell LD. Isolation and characterisation of Campylobacter pyloridis from gastric biopsies. $\mathrm{Br}$ Med $J$ 1986;293: 645-50.

9 McMullen L, Walker MM, Bain IA, Karim QN, Baron JH Histological identification of Campylobacter using the Giminez technique in gastric antral mucosa.J Clin Pathol 1987;40:462.

10 Quinn TC, Goodell SE, Fennell C, Want SP. Infections with Campylobacter jejuni and Campylobacter-like with Campylobacter jejuni and Campylobacter-like
organisms in homosexual men. Ann Intern Med 1984; organisms in

11 Meiseleman MS, Miller-Catchpole R, Christ M, Randall E. Campylobacter pylori in the acquired immunodeficiency syndrome. Gastroenterology 1988;95:209-12.

12 Aceti A, Attanasio R, Pennica A, et al. Campylobacter pylori infection in homosexuals. Lancet 1987;ii:154-5.

13 Ellakany S, Whiteside TL, Shade RR, Van Thiel DH. Analysis of intestinal lymphocyte subpopulations in patients with acquired immunodeficiency (AIDS) and AIDS-related complex. Am J Clin Pathol 1987;87: AIDS-r.

14 Griffin GE, Miller A, Mathan M, et al. Damage of jejunal Griffin GE, Miller A, Mathan M, et al. Damage of jejunal
intrinsic autonomic nerves in human immunodeficiency intrinsic autonomic nerves in human
virus infection. AIDS 1988;2:379-82.

15 Miller ARO, Griffin GE, Batman P, et al. Jejunal mucosal architecture and fat absorbtion in male homosexuals infected with human immunodficiency virus. $Q \mathrm{~J} \mathrm{Med}$ 1988;69:1009-19. 